\title{
A tiered approach to assess effects of diclofenac on the brown mussel Perna perna: A contribution to characterize the hazard
}

\author{
Mayana Karoline Fontes ${ }^{\text {a, b }}$, Paloma Kachel Gusso-Choueri b, Luciane Alves Maranho a, c, \\ Denis Moledo de Souza Abessa ${ }^{b}$, Wesley Almeida Mazur ${ }^{c}$ d, Bruno Galvão de Campos ${ }^{b}$, \\ Luciana Lopes Guimarães ${ }^{c, d}$, Marcos Sergio de Toledo ${ }^{\mathrm{d}}$, Daniel Lebre ${ }^{\mathrm{e}}$, \\ Joyce Rodrigues Marques ${ }^{\mathrm{e}}$, Andreia Arantes Felicio ${ }^{\mathrm{f}}$, Augusto Cesar ${ }^{\mathrm{a}, \mathrm{c}}$, \\ Eduardo Alves Almeida ${ }^{g}$, Camilo Dias Seabra Pereira ${ }^{a, c, *}$ \\ a Departamento de Ciências do Mar, Universidade Federal de São Paulo, Rua Maria Máximo, 168, 11030-100 Santos, Brazil \\ ${ }^{\mathrm{b}}$ Instituto de Biociências, Campus do Litoral Paulista, Universidade Estadual Paulista "Júlio de Mesquita Filho", Infante Dom Henrique, s/n, 11330-900 São \\ Vicente, Brazil \\ ${ }^{c}$ Laboratório de Ecotoxicologia, Universidade Santa Cecília, Rua Oswaldo Cruz 266, 11045-907 Santos, Brazil \\ d Departamento de Bioquímica da Universidade Federal de São Paulo, Rua Botucatu, 862, 04023-901 São Paulo, Brazil \\ e CEMSA - Centro de Espectrometria de Massas Aplicada, CIETEC/IPEN, Av. Prof. Lineu Prestes, 2242, Salas 112 e 113, 05508-000 São Paulo, Brazil \\ ${ }^{\mathrm{f}}$ Universidade Estadual Paulista Júlio de Mesquita Filho - Campus São José do Rio Preto, Rua Cristóvão Colombo 2265, 15054-000 São José do Rio Preto, SP, \\ Brazil \\ ${ }^{\mathrm{g}}$ Fundação Universidade Regional de Blumenau, Rua Antônio da Veiga 498, Itoupava Seca, 89030-103 Blumenau, Brazil
}

\section{A R T I C L E I N F O}

Article history:

Available online 29 December 2017

\section{Keywords:}

Pharmaceuticals

Nonsteroidal anti-inflammatory drug

Marine environment

Non-target organism

\begin{abstract}
A B S T R A C T
Pharmaceutical discharges into the aquatic ecosystem are of environmental concern and sewage treatment plants (STPs) have been pointed out as the major source of these compounds to coastal zones, where oceanic disposal of sewage occurs through submarine outfalls. Diclofenac (DCF) is one of the most frequently detected pharmaceuticals in water, but little is known about the effects on marine organisms. In this study, we employed a tiered approach involving the determination of environmental concentrations of DCF in marine water and the adverse biological effects for fertilization, embryo-larval development and biomarker responses of the mussel Perna perna. Results indicate that effects in fertilization rate and embryo-larval development were found in the order of $\mathrm{mg} \cdot \mathrm{L}^{-1}$. However, low concentrations of DCF $\left(\mathrm{ng} \cdot \mathrm{L}^{-1}\right)$ significantly decreased the lysosomal membrane stability and COX activity, as well as triggered DNA damage, oxidative stress and changes in antioxidant defenses. Our results point to an environmental hazard at coastal ecosystems and suggest the need for improvements in the treatment of domestic wastewater aiming to reduce DCF concentrations, as well as regulation on current environmental legislation and monitoring of aquatic ecosystems.
\end{abstract}

() 2017 Elsevier Ltd. All rights reserved.

\section{Introduction}

The marine environment is exposed to a wide range of pollutants associated with anthropogenic sources, such as metals, polycyclic aromatic hydrocarbons, plastic debris and active pharmaceuticals compounds and their metabolites (AguirreMartínez et al., 2013a; Diniz et al., 2015). Pharmaceutical and

\footnotetext{
* Corresponding author. Departamento de Ciências do Mar, Universidade Federal de São Paulo, Rua Maria Máximo, 168, 11030-100 Santos, Brazil.

E-mail addresses: camilo.seabra@unifesp.br, camilo@unisanta.br (C.D.S. Pereira).
}

Personal Care Products (PPCPs) have been detected in surface waters (Hernando et al., 2006), groundwater (Heberer and Feldmann, 2005), drinking water (Rodil et al., 2012), marine water (Pereira et al., 2016) and Sewage Treatment Plants (STP) were identified as the major source of water contamination (McClellan and Halden, 2010). Although pharmaceuticals have been detected in the environment in trace-concentrations from ng. $\mathrm{L}^{-1}$ to $\mu \mathrm{g} . \mathrm{L}^{-1}$, it has been demonstrated that they can adversely affect the health status of aquatic organisms (Aguirre-Martínez et al., 2013b).

Urban sewage is considered a main cause of marine pollution, especially in coastal areas, due to a high population density. In these areas, two different alternatives have been adopted for 
disposal of urban sewage: oceanic disposal system through a submarine sewage outfall composed of a pre-conditioning plant; 2) primary and secondary treatment of effluent waste release in inland waters. However, some pharmaceuticals are not totally eliminated because the conventional technology of treatment used in STPs is insufficient to completely remove these compounds (Ferrari et al., 2003). Furthermore, the continuous input of pharmaceuticals into the water can give them a pseudo-persistence state (Hernando et al., 2006).

One of most frequently detected pharmaceuticals in water is the Diclofenac (DCF), an anti-inflammatory drug that is widely used as analgesic, antirheumatic compound, antiarthritic, working by cyclooxygenase inhibition and thus blocking the prostaglandin synthesis (van den Brandhof and Montforts, 2010). DCF has a Kow $=4.5$, which makes it a compound with certain lipophilicity, facilitating its bioaccumulation in animal tissues (Cleuvers, 2004). Several studies have demonstrated that DCF exposure induces negative effects in non-target organisms such as alterations and necrosis in trout gills (Hoeger et al., 2005; Triebskorn et al., 2004), impairment of the osmoregulatory ability of crabs (Eades and Waring, 2010), lower scope for growth in mussels (Ericson et al., 2010), bioaccumulation and significant biomarker responses (Gonzalez-Rey and Bebianno, 2014). Moreover, DCF exposure affected larval development of mussels (Fabbri et al., 2014), caused deleterious effects in zebrafish embryos (Feito et al., 2012) oxidative stress in crustaceans (GómezOliván et al., 2014) and affected gill integrity and pituitary gene expression in trout (Gröner et al., 2015, 2017). However, most previous studies have highlighted the adverse effects of DCF in freshwater organisms, and little effort has been applied to the study of the negative effects of this pharmaceutical in marine organisms.

Recently, the European Union established regulatory guidance to assess the presence of pharmaceuticals in the aquatic environment (Directive, 2013/39/EU amending Directives, 2000/60/ EC and 2008/105/EC) (European Commission, 2013) and the priority substances in Water Policy. Moreover, the European Commission updated the monitoring watch list of priority substances in the field of water policy, including the sex hormones 17alpha-ethinylestradiol and 17beta-estradiol, and the nonsteroidal anti-inflammatory (NSAID) DCF (Lolić et al., 2015). In this context, DCF and other pharmaceuticals have been included in monitoring programs and environmental risk assessments around the world, for example in Canada (Kleywegt et al., 2007) and Korea (Han et al., 2006). However, Brazilian regulation on environmental risk assessment and PPCPs discharges remain unchanged (Pereira et al., 2016).

Under this reasoning, the present work assumes that DCF is capable of causing adverse effects in non-target organisms, more specifically the marine bivalve Perna perna, at environmentally relevant concentrations, denoting the ecological risk of this drug. Bivalve mollusks as Perna perna play an important role at aquatic ecosystems. They are sessile and filter large quantities of surface water for feeding and respiration, besides to accumulate organic pollutants and metals, and these are highly desirable features in ecotoxicological studies (Rittschof and McClellan-Green, 2005).

Our study aimed to conduct an ecotoxicological study using a tiered approach to determine the environmental concentration in the water column and associated adverse biological effects. This approach included: a) identification and quantification of this pharmaceutical in marine water sampled near the disposal area of the submarine sewage outfall; b) acute toxicity tests assessing reproduction endpoints; c) 96-h exposure assay for the evaluation of sublethal responses through biomarkers.

\section{Material and methods}

\subsection{Chemicals}

Standards of DCF (2-[(2,6-dichlorophenyl)amino]benzeneacetic acid, CAS number 15307-79-6, purity $\geq 98 \%$ ) were obtained from Sigma-Aldrich (Steinheim, Germany), as well as all other chemicals used for fertilization and embryo-larval development assays and biomarkers analysis.

\subsection{Tier 0}

\subsubsection{Sampling sites}

Water column sampling was conducted at 6 sampling sites surrounding the submarine sewage outfall in Santos Bay during December of 2016, considering all possibilities for plume dispersion (Fig. 1). Surface $(1 \mathrm{~m})$ and bottom $(10 \mathrm{~m})$ waters were sampled employing a Van Dorn bottle.

\subsubsection{Sample preparation}

For field water samples and spiked water samples analysis, the extraction was performed according Pereira et al. (2016). Solid phase extraction (SPE) employed Chromabond HR-X cartridges ( $3 \mathrm{~mL}, 200 \mathrm{mg}$, Macherey-Nagel, Düren, Germany), according to Wille et al. (2010). Prior to mass spectrometry analysis, samples were dried with nitrogen and eluted with water/acetonitrile solution $(95: 5, \mathrm{v} / \mathrm{v})$.

\subsubsection{LC-MS/MS analysis}

For analysis of field water samples, $10 \mu \mathrm{L}$ of each sample was analyzed by an HPLC Agilent 1260 (Agilent Technologies, CA, USA) combined with a 3200 QTRAP hybrid triple quadrupole/LIT (linear ion trap) mass spectrometer ABSciex, Ontario (Canada). Samples were analyzed by an Agilent Eclipse XDB-C18 $4.6 \times 50 \mathrm{~mm}, 1.8 \mu \mathrm{m}$ column at $25^{\circ} \mathrm{C}$, and the mobile phase was in $0.1 \%$ formic acid (Sigma-Aldrich LC-MS Grade) in water (solvent A) and acetonitrile (J.T. Baker LC-MS Grade) (solvent B). DCF was detected and quantified using ESI ionization (positive mode) and Multiple Reaction Monitoring (MRM) mode. MRM parameters are described in Table 1..

For determination of DCF concentration in the bioassays, $1 \mathrm{~L}$ of the spiked water was collected at the beginning of the experiment and $24 \mathrm{~h}$ later (at the end of the bioassays). They were then prepared as the environmental samples, and mass spectrometry analysis were performed using a Varian 310 Triple-Quadrupole mass spectrometry (Varian Inc., Walnut Creek, CA) with an ESI source (ESI-MS), by direct infusion. Data acquisition was controlled with Varian MS Workstation version 6.9 (Varian Inc.). Sample analysis was carried out in positive ESI mode with a needle voltage of $20 \mathrm{kV}$. The capillary temperature was $200^{\circ} \mathrm{C}$, the drying gas pressure was $20 \mathrm{psi}$ and the nebulizing gas pressure was $40 \mathrm{psi}$. DCF was detected and quantified using Multiple Reaction Monitoring (MRM) mode, with the selection of a precursor ion $(296.1 \mathrm{~m} / \mathrm{z})$ and two ion products to quantify and qualify DCF (214.1 and $205.0 \mathrm{~m} / \mathrm{z}$, respectively) A matrix-matched calibration curve was employed, as described by Wille et al. (2010).

\subsection{Tier 1}

\subsubsection{Mussel acclimation and maintenance conditions}

Adult mussels were acquired from a mussel farming located in Toque Beach (São Sebastião, SP, Brazil), due to its good environmental status (CETESB, 2016). Mussels were kept in the lab with food supply for $72 \mathrm{~h}$ for acclimation.

Physical-chemical parameters of the reconstituted seawater and 


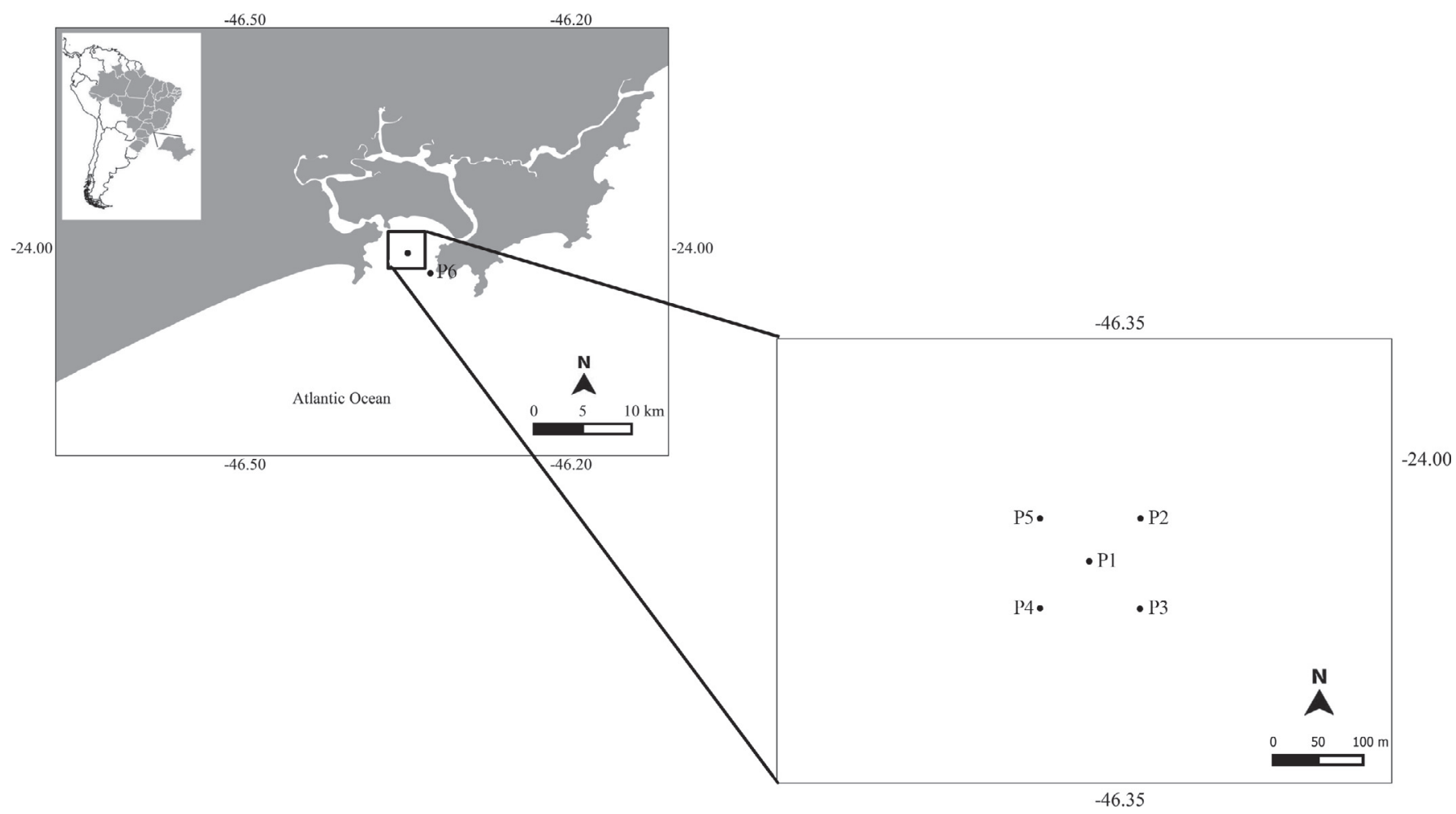

Fig. 1. Sampling stations located adjacent to submarine sewage outfall in Santos Bay.

Table 1

Parameters of Multiple Reactions Monitoring for the positive and negative ion mode, limit of detection, limit of quantification and retention time.

\begin{tabular}{|c|c|c|c|c|c|c|c|c|}
\hline Compounds & Q1 & Q3 & $\mathrm{DP}(\mathrm{V})$ & $\mathrm{CE}(\mathrm{V})$ & $\operatorname{CXP}(\mathrm{V})$ & $\mathrm{LOD}\left(\mathrm{ng} \cdot \mathrm{L}^{-1}\right)$ & $\operatorname{LOQ}\left(\mathrm{ng} \cdot \mathrm{L}^{-1}\right)$ & RT (min.) \\
\hline \multirow[t]{3}{*}{ Diclofenac } & 296.1 & 214.1 & 21 & 39 & 4 & 0.81 & 3.0 & 5.77 \\
\hline & & 250.0 & 21 & 25 & 4 & & & \\
\hline & & 207.1 & 21 & 33 & 4 & & & \\
\hline
\end{tabular}

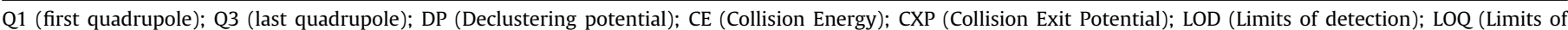
quantification); RT (Retention Time); MIM (Multiple ion monitoring). In Q3, in the upper cell is the quantifier ion and in the lower cell is the qualifier ion.

treatments were measured at the beginning and at the end of the assays (fertilization and embryo-larval assays), or at every replacement of test solutions (NRRT assays, session 2.4.1.1). Temperature ranged from $21^{\circ} \mathrm{C}$ to $23^{\circ} \mathrm{C}$, pH ranged from 8.1 to 8.25 , salinity ranged from 34 to $36 \mathrm{PSU}$, and dissolved oxygen ranged from 6.0 to $6.8 \mathrm{mg} \cdot \mathrm{L}^{-1}$.

\subsubsection{Fertilization and embryo-larval development assays}

Fertilization assay was performed following USEPA protocol (2002) adapted to Perna perna according to Zaroni et al. (2005). The gametes (eggs and sperm) were obtained by thermal stimulation (from $10^{\circ} \mathrm{C}$ to $30^{\circ} \mathrm{C}$ ) of fifty individuals during $30 \mathrm{~min}$. The eggs solution was filtered in a $0.75 \mu \mathrm{m}$ membrane. From the sperm solution, about $2 \mathrm{~mL}$ were diluted in $48 \mathrm{~mL}$ of reconstituted seawater. Given the lipophilic nature of DCF and its low water solubility (23.73 mg/L at $25^{\circ} \mathrm{C}$; Research Corporation, 2006), dimethyl sulfoxide (DMSO) was used as carrier solvent (Parolini et al., 2011). A solvent concentration of $1 \mu \mathrm{l} . \mathrm{L}^{-1}$ was used in each DCF concentration. So, a DCF working solution (1000 mg.. $\mathrm{L}^{-1}$ ) was prepared by diluting $100 \mathrm{mg}$ of DCF in $60 \mu \mathrm{L}$ of DMSO. From this stock solution all DCF test solutions were prepared $(31.25 ; 62.5 ; 125 ; 250 ; 500$ and $1000 \mathrm{mg} \mathrm{L}^{-1}$ ). The sperm was exposed to two controls (seawater and seawater plus DMSO $1 \mu \mathrm{l} . \mathrm{L}^{-1}$ ) for $60 \mathrm{~min}$, in quadruplicate.

Then, approximately 2000 ovules were added to each tube and after 45 min were added $500 \mu \mathrm{L}$ of formaldehyde. 100 eggs from each replicate were assessed and the observation of a fertilization membrane or the beginning of cellular divisions was employed to identify fertilization. Three assays were performed to obtain a mean value of DCF concentration causing fertilization inhibition at $50 \%$ of exposed ovules $\left(\mathrm{IC}_{50}\right)$.

The embryo-larval development assay was performed according to the protocol recommended by ASTM (1992) for mussels, with minor adaptations proposed by Zaroni et al. (2005). Fifty individuals were induced to spawn (as described in section 2.3.2 for the detailed characterization of this procedure). The gametes were collected separately and the fertilization was induced adding $2 \mathrm{~mL}$ of sperm solution to a 2000 ovules solution. When the cleavages began, about 500 embryos were added to each test-tube containing different concentrations of DCF $\left(0.01 ; 0.1 ; 1 ; 10\right.$ and $\left.100 \mathrm{mg} \mathrm{L}^{-1}\right)$. The test duration was $48 \mathrm{~h}$ at $25^{\circ} \mathrm{C}$ and salinity of $35 \mathrm{PSU}$. The assay was conducted in quadruplicate and employed two controls (seawater and seawater plus DMSO $1 \mu \mathrm{l} . \mathrm{L}^{-1}$ ), since a solvent concentration of $1 \mu$ l.L- 1 was used in each DCF concentration. The first 100 larvae from each test-tube were assessed, considering a " $D$ shape" as regular development. The assay was performed three times to obtain mean values of DCF concentration that cause embryo-larval development inhibition of $50 \%$ of the exposed organisms $\left(\mathrm{IC}_{50} ; 48 \mathrm{~h}\right)$, the No Observable Effect Concentration 
(NOEC) and the Lowest Observable Effect Concentration (LOEC) means.

\subsection{Tier 2. biomarkers responses}

\subsubsection{Biomarker assay}

2.4.1.1. Mussel exposure. Mussel P. perna $(\mathrm{n}=80,60 \pm 1 \mathrm{~mm})$ were acclimatized for one week in a $300 \mathrm{~L}$ aquarium filled with seawater under controlled conditions. After this period, the mussels $(n=10$, 1 mussel $\mathrm{L}^{-1}$ ) were exposed in aquaria to different concentrations of DCF (20; 200 and $\left.2000 \mathrm{ng} \mathrm{L}^{-1}\right)$, and a solvent concentration of $1 \mu \mathrm{l} . \mathrm{L}^{-1}$ was used in each DCF concentration. These concentrations were chosen based on data obtained from environmental monitoring performed by Pereira et al. (2016), which found a concentration of $19.4 \mathrm{ng} \mathrm{L}^{-1}$ of DCF in Santos Bay. A solvent control (1 $\left.\mu \mathrm{l} . \mathrm{L}^{-1}\right)$ was set in parallel with the DCF bioassay, and for each treatment, two aquaria of $10 \mathrm{~L}$ and 10 animals per aquaria were used. Seawater was changed daily (24 h) and DCF nominal concentration was restored. Seawater was filtered $(200 \mu \mathrm{m})$ providing phytoplankton as mussels' food source, and no additional food was added. For each 48 and $96 \mathrm{~h}$ of exposure, the mussels were removed from the aquaria for haemolymph extraction.

Before the bioassay has started, lysosomal membrane stability (LMS) was determined in some specimens from the acclimated aquaria, to certify the health status of the organisms that were exposed to the DCF concentrations. LMS was determined by Neutral Red Retention Time (NRRT) method (Lowe and Pipe, 1994).

2.4.1.2. Neutral Red Retention Time assay (NRRT). This method is applied to haemolymph withdrawn from the posterior adductor muscle of living bivalves, as described by Lowe and Pipe (1994). The endpoint was the time when at least $50 \%$ of the examined cells by optical microscopy $(400 \times)$ exhibited dye loss from the lysosomes to the cytosol. After the withdrawal of their haemolymph, each mussel was dissected, and gill and digestive gland were stored at $-80^{\circ} \mathrm{C}$ until the biomarkers' analyses.

2.4.1.3. Tissue preparation. Gills and digestive gland from each individual were excised and homogenized (homogenized fraction- $-\mathrm{HF}$ ) in a Tris- $\mathrm{HCl}$ buffer. An aliquot of the homogenate was separated for the analysis of DNA damage and lipid peroxidation. Another aliquot was centrifuged at $15,000 \times \mathrm{g}$ for $20 \mathrm{~min}$ at $4{ }^{\circ} \mathrm{C}$ and the supernatant were employed for biomarkers determinations (EROD, DBF, GST, GPX, AChE and COX). Total protein was determined for both aliquots and tissues according to Bradford (1976).

2.4.1.4. Ethoxyresorufin O-deethylase (EROD). Ethoxyresorufin Odeethylase activity was assessed by the transformation of 7ethoxyresorufin in resorufin at $485 \mathrm{~nm}$ (excitation) and $580 \mathrm{~nm}$ (emission) according to Gagné and Blaise (1993). Results were expressed as $\mathrm{pmol} / \mathrm{min} / \mathrm{mg}$ protein.

2.4.1.5. Dibenzylfluorescein dealkylase (DBF). The activity of Dibenzylfluorescein dealkylase was evaluated employing the method described by Gagné et al. (2007). Fluorescence was measured at $485 \mathrm{~nm}$ (excitation) and $516 \mathrm{~nm}$ (emission) and results were expressed as $\mathrm{pmol} / \mathrm{min} / \mathrm{mg}$ protein.

2.4.1.6. Glutathione S-transferase activity (GST). Glutathione Stransferase activity was determined by the method adapted from McFarland et al. (1999). The rate of reaction was measured by absorbance in a spectrophotometer at $340 \mathrm{~nm}$ at every $5 \mathrm{~min}$ for $30 \mathrm{~min}$ at $30^{\circ} \mathrm{C}$. Results were expressed as $\mathrm{OD} / \mathrm{min} / \mathrm{mg}$ proteins.
2.4.1.7. Glutathione peroxidase activity (GPX). Glutathione peroxidase activity was determined following the protocol employed by McFarland et al. (1999). Absorbance at $340 \mathrm{~nm}$ was measured every $30 \mathrm{~s}$ for $30 \mathrm{~min}$ and results were expressed as nmol/min/mg protein.

2.4.1.8. DNA damage. DNA damage was assessed by the alkaline precipitation assay (Olive, 1988) using fluorescence to measure DNA strand breaks (Gagné et al., 1995). DNA strands were quantified using fluorescence $360 \mathrm{~nm}$ (excitation) and $450 \mathrm{~nm}$ (emission) after staining with Hoechst dye. Standard solutions of salmon sperm DNA were used for calibration. Results were expressed as $\mu \mathrm{g}$ DNA strands/mg protein.

2.4.1.9. Lipid peroxidation. Levels of MDA in tissues were quantified according to Hong et al. (2000) by HPLC coupled to an UV/Vis detector set at $532 \mathrm{~nm}$. The MDA quantification was established on a calibration curve using as standard MDA obtained by tetramethoxypropane hydrolysis. Chromatogram monitoring and peak identification and quantification were performed using the EZ Chrom Elite software (Agilent Technologies). Results were expressed as pmol TBARS/mg tissue.

2.4.1.10. Cholinesterase (ChE). Cholinesterase activity was evaluated by the method described by Ellman et al. (1961). The absorbance at $412 \mathrm{~nm}$ was measured every $1 \mathrm{~min}$ for $7 \mathrm{~min}$. Results were expressed as nmol $\mathrm{min} / \mathrm{mg}$ protein.

2.4.1.11. Cyclooxygenase (COX). COX activity was measured as described by Fujimoto et al. (2002). The samples were incubated in $50 \mathrm{mM}$ Tris- $\mathrm{HCl}, 0.05 \%$ Tween-20, $50 \mu \mathrm{M}$ arachidonate, $2 \mu \mathrm{M}$ dichlorofluorescein and $0.1 \mu \mathrm{g} \mathrm{mL}^{-1}$ horseradish peroxidase. Fluorescence was measured at $485 \mathrm{~nm}$ and $530 \mathrm{~nm}$ and results were expressed as $\mathrm{RFU} / \mathrm{min} / \mathrm{mg}$ protein.

\subsection{Statistical analysis}

For the fertilization assay, an $\mathrm{EC}_{50}$ was calculated by Trimmed Spearman-Karber. The linear interpolation method was used to calculate the IC50 ( $48 \mathrm{~h}$ ) for the embryo-larval development assay. Biomarker results of T0, water and solvent controls (DMSO) were analyzed by ANOVA and showed no significant differences. Thus, two-way ANOVA followed by the Dunnett's test were used to identify the concentrations which were significantly different, as well as differences between the periods analyzed, employing solvent control as a reference. Statistical differences were considered significant when $\mathrm{p} \leq .05$. Prism v.7a Software was employed for ANOVA and post hoc analysis.

\section{Results}

\subsection{Environmental concentration}

The environmental concentrations of DCF are shown in Table 2. DCF was quantified in Station 1 (surface and bottom) and detected in Station 4 (bottom), but it was not detected in the reference sampling station (6).

\subsection{Fertilization and embryo-larval development assays}

The measured concentrations of DCF at the beginning of the exposure experiment for the in fertilization and embryo-larval assays (T0) and after $24 \mathrm{~h}$ (T24h) are shown in Table 3.

Fertilization rate was significantly inhibited at all concentrations tested $(\mathrm{p}<.05)$ so that a NOEC could not be provided. The LOEC of 
Table 2

Environmental concentration of DCF in surface and bottom water samples (1-6 sampling stations) from Santos Bay.

\begin{tabular}{|c|c|c|c|c|c|c|}
\hline & \multicolumn{6}{|c|}{ DCF concentration (ng. $\mathrm{L}^{-1}$ ) } \\
\hline & 1 & 2 & 3 & 4 & 5 & 6 \\
\hline Surface & 4.01 & $<$ LOD & $<$ LOD & $<$ LOD & $<$ LOD & $<\mathrm{LOD}$ \\
\hline Bottom & 4.78 & $<$ LOD & $<$ LOD & $<$ LOQ & $<\mathrm{LOD}$ & $<$ LOD \\
\hline
\end{tabular}

$<$ LOD, below limit of detection. $<$ LOQ below limit of quantification.

Table 3

Measured concentrations of DCF in spiked water of fertilization and embryo-larval assays.

\begin{tabular}{lrrr}
\hline Nominal concentration (mg. $\mathrm{L}^{-1}$ ) & \multicolumn{2}{l}{$\begin{array}{l}\text { Measured } \\
\text { concentration }\end{array}$} & Reduction (\%) \\
\cline { 2 - 3 } & $\mathrm{t}$ 0 & $\mathrm{t} \mathrm{24}$ & \\
\hline 0.01 & 0.0093 & 0.0003 & 96.77 \\
1.0 & 1.5207 & 0.0454 & 97.01 \\
31.25 & 41.3400 & 0.8300 & 97.99 \\
100.0 & 104.5013 & 3.5339 & 96.61 \\
250.0 & 260.3400 & 8.0100 & 96.93 \\
1000.0 & 1013.9600 & 13.0800 & 98.71 \\
\hline
\end{tabular}

t0, beginning of the experiment; t24, after $24 \mathrm{~h}$ of exposure.

the DCF was $31.25 \mathrm{mg} \mathrm{L}^{-1}$ and the $\mathrm{EC}_{50}$ was estimated at $389 \mathrm{mg} \mathrm{L}^{-1}$ after $24 \mathrm{~h}$ of exposure (95\% confidence of interval: $356 \mathrm{mg} \mathrm{L}^{-1}$. $407 \mathrm{mg} \mathrm{L}^{-1}$ ). Furthermore, there was no statistically significant difference between the control and the solvent control with DMSO ( $\mathrm{p}>.05)$ (Fig. 2A). Only the highest DCF concentration caused a significant inhibition of embryo-larval development compared to controls $\left(\mathrm{p}<.05\right.$ ) (Fig. 2B). The NOEC was at $10 \mathrm{mg} \mathrm{L}^{-1}$, the LOEC of the DCF was $100 \mathrm{mg} \mathrm{L}^{-1}$ and the $\mathrm{IC}_{50}$ was $18 \mathrm{mg} \mathrm{L}^{-1}$ after $48 \mathrm{~h}$ of exposure (95\% confidence of interval: $16.3 \mathrm{mg} \mathrm{L}^{-1}-20 \mathrm{mg} \mathrm{L}^{-1}$ ).

\subsection{Biomarker responses}

The measured concentrations of DCF at the beginning of the exposure experiment for the biomarkers assays (T0) and after $24 \mathrm{~h}$ (T24h) are shown in Table 4.

There was no statistically significant difference between water control and the solvent control ( $p>.05)$, therefore, the concentration of DMSO applied to prepare DCF stocks did not have a toxic effect in exposed mussels. For all biomarkers, only solvent control DMSO was considered for statistical analysis.

The LMS of Perna was significantly affected $(\mathrm{p}<.05)$ compared with control organisms, at all concentrations tested. After $48 \mathrm{~h}$ of exposure, the organisms exposed to all concentrations showed a significant decrease in the retention time of the dye. At 20 ng. $\mathrm{L}^{-1}$ the NRRT was reduced by $65 \%$ ( $23.57 \mathrm{~min}$ ); at $200 \mathrm{ng} . \mathrm{L}^{-1}$ by $52 \%$ (32.14 min) at $2000 \mathrm{ng} . \mathrm{L}^{-1}$ by $58 \%(25.5 \mathrm{~min})$. The reduction also occurred after $96 \mathrm{~h}$ of exposure. At $20 \mathrm{ng} . \mathrm{L}^{-1}$ the NRRT was reduced by $46 \%$ ( $35.5 \mathrm{~min}$ ); at 200 ng. $\mathrm{L}^{-1}$ was reduced by $47 \%$ (28.3 $\mathrm{min}$ ) and at 2000 ng.L . $^{-1}$ was reduced by $47 \%$ (28.2 min) (Fig. 3).

For gill tissues, EROD activity was inhibited at $200 \mathrm{ng}$. $\mathrm{L}^{-1}$, but not at 20 and 2000 ng. $\mathrm{L}^{-1}$ during $96 \mathrm{~h}$ exposure ( $<<.05$ ) (Fig. 4). EROD activity in the digestive gland exposed to DCF showed no significant differences between concentrations tested compared to controls $(p>.05)$ and there were also no significant differences between the times analyzed ( $\mathrm{p}>.05$ ) (Fig. 5). DBF activity in the digestive gland tissues (Fig. 5) showed no significant differences between concentrations compared to controls and no significant differences between exposure times ( $\mathrm{p}>.05$ ).

DCF inhibited significantly the GST activity in gill tissues (Fig. 4) at all concentrations tested after $48 \mathrm{~h}$ exposure $(\mathrm{p}<.05)$, while at
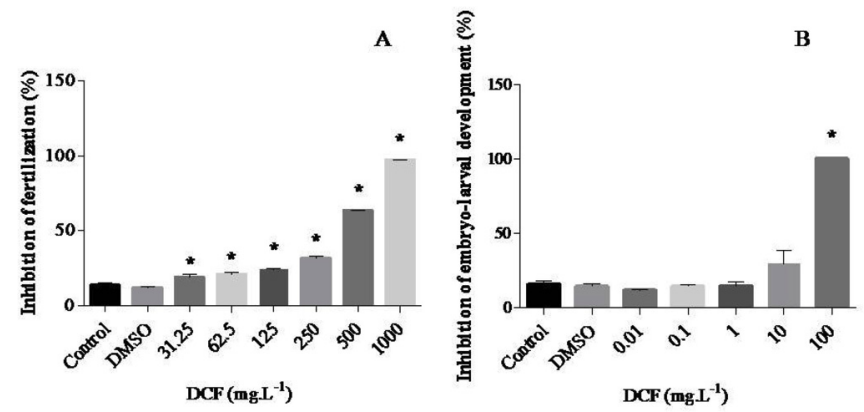

Fig. 2. Inhibition of fertilization (A) and embryo-larval development (B) in Perna perna after exposure to different concentrations of DCF (ANOVA - Dunnett's test, $\mathrm{p}<.05$ ). Error bars indicate the standard errors.

Table 4

Measured concentration of DCF in spiked water of biomarkers assays.

\begin{tabular}{llll}
\hline Nominal concentration (ng.L $\mathrm{L}^{-1}$ ) & \multicolumn{2}{l}{$\begin{array}{l}\text { Measured } \\
\text { concentration }\end{array}$} & Reduction (\%) \\
\cline { 2 - 4 } & t 0 & t 24 & \\
\hline 20 & 22.71 & $<$ LOQ & ND \\
200 & 211.33 & 7.20 & 96.59 \\
2000 & 2214.66 & 77.69 & 96.49 \\
\hline
\end{tabular}

t0, beginning of the experiment; t24, after $24 \mathrm{~h}$ of exposure. ND, not determined.

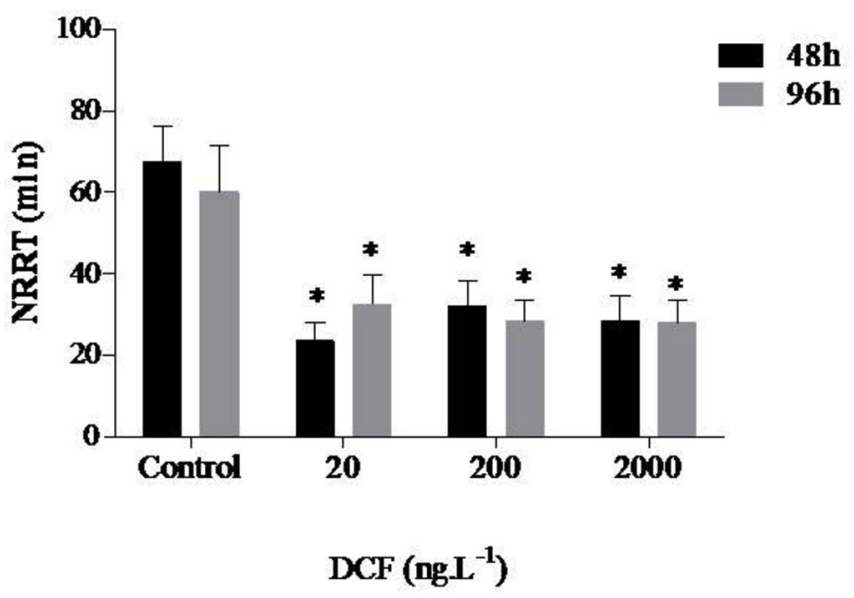

Fig. 3. NRRT in hemocytes of Perna perna exposed to DCF (ANOVA - Dunnett's test, $\mathrm{p}<.05$ ). Asterisks indicate significance compared to control. Error bars indicate the standard errors.

$96 \mathrm{~h}$ exposure only the highest concentration (2000 ng. $\mathrm{L}^{-1}$ ) showed significantly lower GST activity compared to control and with the activity measured after $48 \mathrm{~h}$ exposure $(\mathrm{p}<.05)$. In addition, between the times, there was a significant difference between controls $(\mathrm{p}<.05)$, being possible to observe that $96 \mathrm{~h}$ exposure has a lower GST activity than after $48 \mathrm{~h}$ exposure (Fig. 4). With respect to digestive gland tissues, none of the concentrations tested were able to induce any change over the control, but GST activity was significantly different between times in all treatments (Fig. 5).

GPx activity in the gill tissues was inhibited at $200 \mathrm{ng} . \mathrm{L}^{-1}$ after $48 \mathrm{~h}$ exposure, and a significantly different inhibition occurred at the highest concentration (2000 ng. $\mathrm{L}^{-1}$ ) after 96h exposure $(\mathrm{p}<.05)$, but no significant differences were observed between the times analyzed (Fig. 4). Similarly, for the digestive gland tissues, no significant difference was observed between the concentrations and the control or between the times analyzed ( $p>.05$ ) (Fig. 5). 

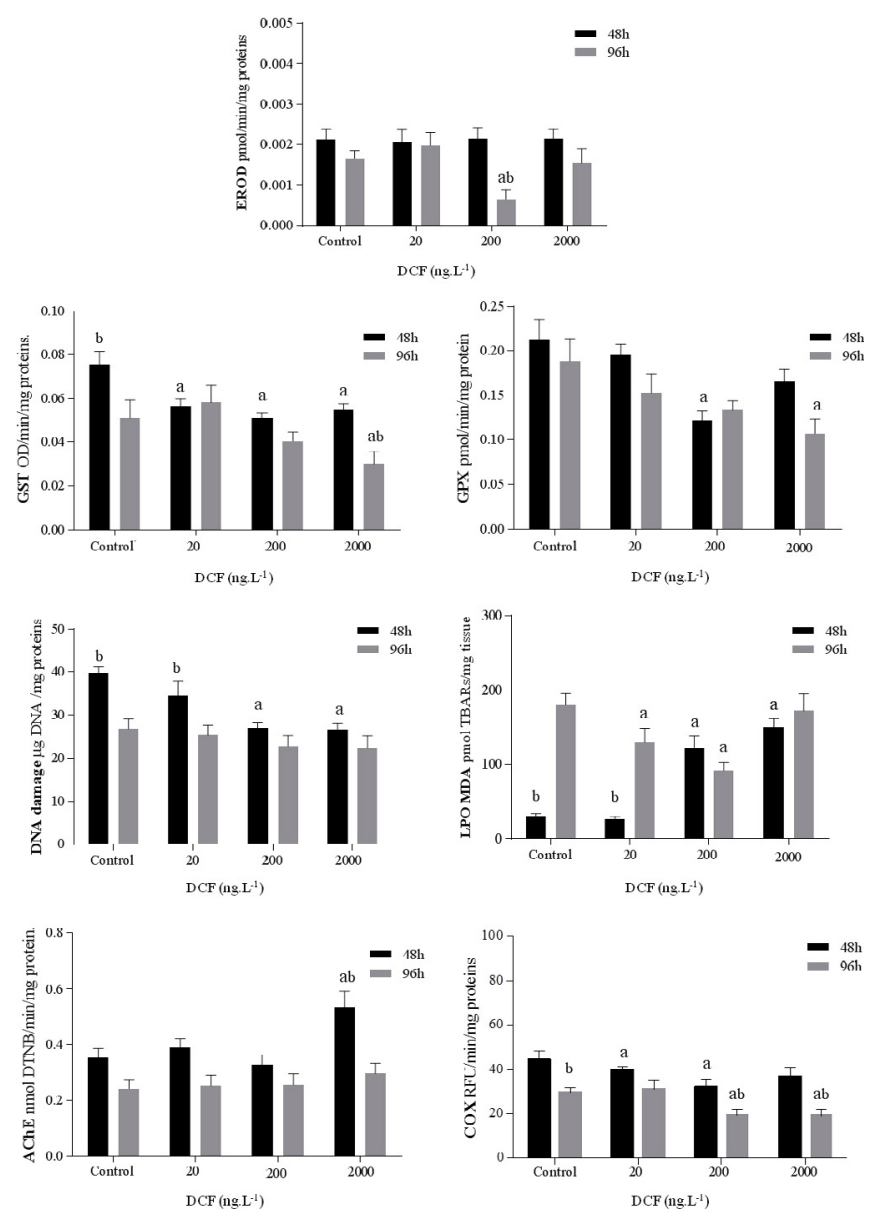

Fig. 4. Biochemical biomarkers in gill tissues of $P$. perna exposed to DCF. Letter A indicates significant differences from control (ANOVA - Dunnett's test, $\mathrm{p}<.05$ ); letter B indicates significant differences between times (ANOVA - Dunnett's test, $\mathrm{p}<.05$ ). Error bars indicate the standard errors.

Gills tissues (Fig. 4) showed a significant decrease in DNA damage for $200 \mathrm{ng} \cdot \mathrm{L}^{1}$ and $2000 \mathrm{ng} . \mathrm{L}^{-1}$, compared to control, after $48 \mathrm{~h}$ exposure $(\mathrm{p}<.05)$. The DNA damage was also significantly different between periods within control and the concentration of 20 ng. $\mathrm{L}^{-1}$ showed a greater damage after $48 \mathrm{~h}$ exposure. However, for the digestive gland tissues (Fig. 5), the highest DNA damage values were measured only at the highest concentration of 2000 ng. $\mathrm{L}^{-1}$ after $48 \mathrm{~h}$ exposure $(\mathrm{p}<.05)$. No significant differences were observed between periods analyzed $(p>.05)$.

LPO levels were measured through MDA quantification. In the gill tissues (Fig. 4), $200 \mathrm{ng} . \mathrm{L}^{-1}$ and $2000 \mathrm{ng} . \mathrm{L}^{-1}$ concentrations showed LPO levels significantly higher than control after $48 \mathrm{~h}$ exposure $(\mathrm{p}<.05)$. Significant induction $(\mathrm{p}<.05)$ of LPO was also observed in gills tissue exposed to $20 \mathrm{ng} . \mathrm{L}^{-1}$ concentration after $96 \mathrm{~h}$ exposure. Furthermore, between times, LPO levels showed significant difference within control and within the concentration of $20 \mathrm{ng}$. $\mathrm{L}^{-1}(\mathrm{p}<.05)$, observable after an increase of LPO during $96 \mathrm{~h}$ exposure (Fig. 4). Digestive gland tissues showed significantly lower LPO levels compared to control when exposed to $200 \mathrm{ng}$. $\mathrm{L}^{-1}$ and after $96 \mathrm{~h}$ exposure $(\mathrm{p}<.05)$. Furthermore, LPO levels were significantly different between times within the control for concentrations of $20 \mathrm{ng} . \mathrm{L}^{-1}$ and $2000 \mathrm{ng} . \mathrm{L}^{-1}$ (Fig. 5).

ChE activity was induced in the gill tissues (Fig. 4) at the highest concentration $\left(2000 \mathrm{ng} . \mathrm{L}^{-1}\right)$ at $48 \mathrm{~h}$ of exposure $(\mathrm{p}<.05)$. At the same concentration, it was also possible to observe that there was a significant difference in the enzymatic activity between times
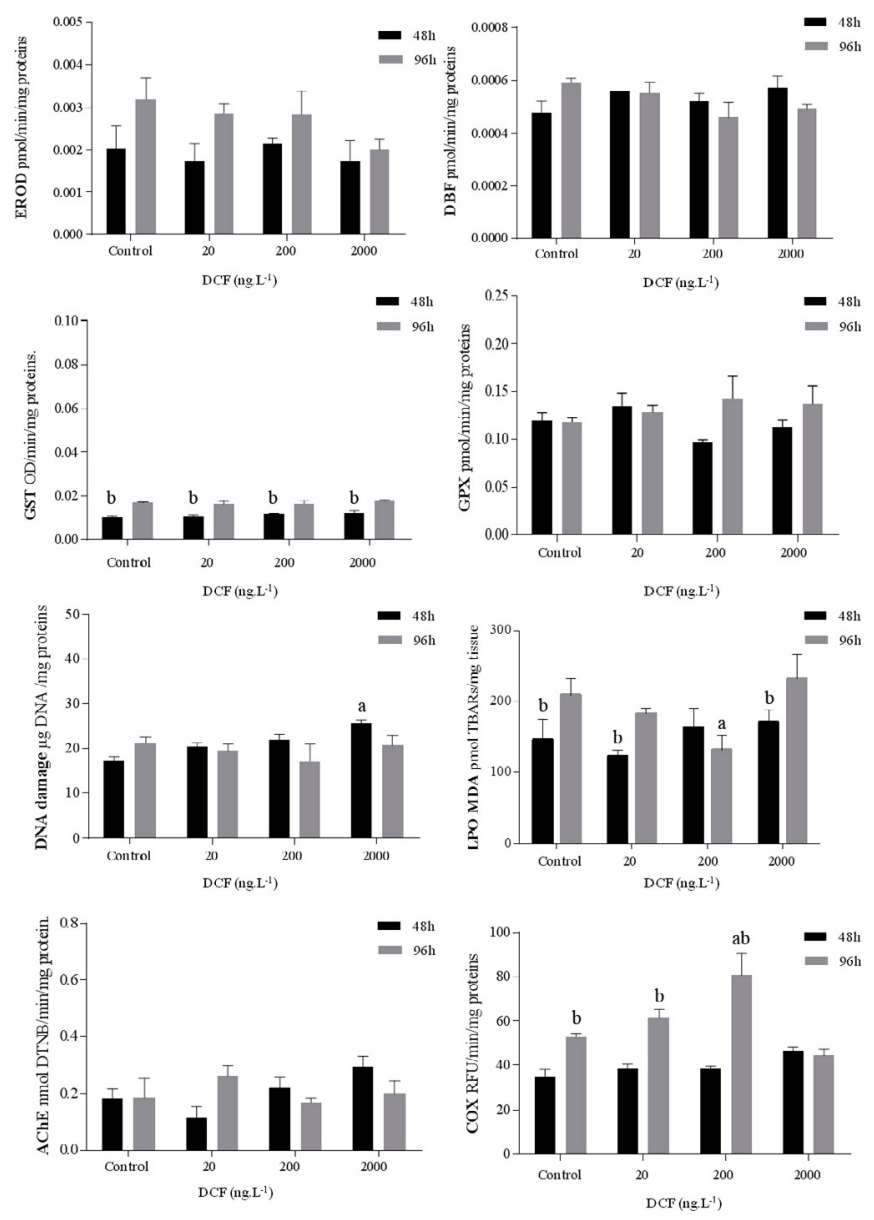

Fig. 5. Biochemical biomarkers in digestive glands tissue of $P$. perna exposed to DCF Letter A indicates significant differences from control (ANOVA - Dunnett's test, $\mathrm{p}<.05$ ); letter B indicates significant differences between times (ANOVA, $\mathrm{p}<.05$ ). Error bars indicate the standard errors.

$(\mathrm{p}<.05)$. However, in the digestive gland tissue, no significant differences were observed between different concentrations and control or between times analyzed ( $\mathrm{p}>.05$ ) (Fig. 5).

COX activity was significantly inhibited in the gill tissues (Fig. 4) at concentrations of $20 \mathrm{ng} . \mathrm{L}^{-1}$ and $200 \mathrm{ng} . \mathrm{L}^{-1}$ after $48 \mathrm{~h}$ exposure $(\mathrm{p}<.05)$ and for $200 \mathrm{ng} . \mathrm{L}^{-1}$ and $2000 \mathrm{ng} . \mathrm{L}^{-1}$ after $96 \mathrm{~h}$ exposure. Between times, lower activity was observed at $96 \mathrm{~h}$ exposure for control and for concentrations of $200 \mathrm{ng} . \mathrm{L}^{-1}$ and $2000 \mathrm{ng} . \mathrm{L}^{-1}$. However, DCF induced a significantly increase in the COX activity for the digestive gland tissues (Fig. 5) at a concentration of 200 ng. $\mathrm{L}^{-1}$ after $96 \mathrm{~h}$ exposure compared to control $(\mathrm{p}<.05)$. There was a significant difference in activity between times within control and for concentrations of 200 ng. $\mathrm{L}^{-1}$ and 2000 ng. $\mathrm{L}^{-1}$, and it was possible to observe an increased activity after $96 \mathrm{~h}$ exposure. No significant difference was observed after $48 \mathrm{~h}$ exposure $(\mathrm{p}>.05)$.

\section{Discussion}

In a previous study in Santos Bay (Pereira et al., 2016), DCF was quantified only in the surface water sample $\left(19.4 \mathrm{ng} . \mathrm{L}^{-1}\right)$, whereas in the current study DCF was quantified in surface and bottom samples from station 1 , and detected in station 4 (bottom). The occurrence of DCF, especially in the bottom samples, is partially explained by the lower sunlight in these samples, avoiding photodegradation (Baena-Nogueras et al., 2017). DCF has a short half- 
life, and it is considered a pseudo-persistent contaminant because of the continuous release in the environment and the inefficiency of conventional effluent treatment processes, which are not able to completely remove residual drugs (Hernando et al., 2006; Gröner et al., 2017).

Degradation assays with DCF under controlled conditions have demonstrated that the sunlight is a crucial factor for DCF degradation (Poirier-Larabie et al., 2016). DCF concentrations found in Santos bay are within the range found in previous studies in seawater. Gros et al. (2012) found lower concentrations (4.0 ng . $\left.\mathrm{L}^{-1}\right)$ in the Mediterranean Sea, whereas Fang et al. (2012) found an intermediate concentration of $53.60 \mathrm{ng} . \mathrm{L}^{-1}$ in coastal waters of Taiwan. The study carried out by Lolić et al. (2015) reported higher concentrations of DCF (241 ng. $\mathrm{L}^{-1}$ ) in North Portugal.

There are few data available relating pharmaceutical exposure in the marine environment and the adverse effects in organisms from tropical coastal regions. Most studies have been evaluating the acute toxicity of DCF in freshwater environments, and different $\mathrm{EC}_{50}$ values have been obtained such as $5.3 \mathrm{mg} . \mathrm{L}^{-1}$ (after $72 \mathrm{~h}$ exposure) for Danio rerio (van den Brandhof and Montforts, 2010), $27.8 \mathrm{mg} \mathrm{.L} \mathrm{L}^{-1}$ (after $24 \mathrm{~h}$ exposure) for Vibrio fischeri (Schmidt et al., 2011), $68 \mathrm{mg} \mathrm{.L}^{-1}$ (after $24 \mathrm{~h}$ exposure) for Daphnia magna (Cleuvers, 2003, 2004). Liu et al. (2017) showed that Daphnia magna exposed to DCF at $50 \mu \mathrm{g} . \mathrm{L}^{-1}$ may present a delay in egg production, suggesting that reproductive parameters are a sensitive endpoint for DCF toxicity to aquatic invertebrates.

Toxicity tests using early life stages of marine organisms (gametes, embryos and larval stages) have been applied to analyze the toxicity of certain substances in a faster and more economical way (Aguirre-Martínez et al., 2015). In our study, acute toxicity was evaluated through fertilization $\left(\mathrm{EC}_{50}=389 \mathrm{mg} . \mathrm{L}^{-1}\right)$ and embryo larval development assays $\left(\mathrm{IC}_{50}=18.04 \mathrm{mg} . \mathrm{L}^{-1}\right)$ and our results showed that DCF might affect the reproduction of Perna perna mussels. The larval development of Ruditapes philippinarum exposed to DCF concentrations of $0.5 \mu \mathrm{g} . \mathrm{L}^{-1}$ was also negatively affected (Munari et al., 2016). Fabbri et al. (2014) have shown that even lower concentrations ( $10 \mathrm{ng} . \mathrm{L}^{-1}$ ) may cause changes in larval development of Mytilus galloprovincialis, suggesting that the early life stages are particularly affected by this compound, because newly hatched larvae constitute a particularly critical and sensitive life stage. Aguirre-Martínez et al. (2015) observed that embryos of sea urchin may lose their protective membrane at hatching, and so may more exposed to potential toxicants. Ericson et al. (2010) noted that concentrations of $10 \mathrm{mg}$. $\mathrm{L}^{-1}$ of DCF significantly lowered scope for growth and byssus strength in mussels Mytilus edulis trossulus.

The analysis of the toxic effects caused by certain contaminants should take into account not only the exposure time to the contaminant, but also the route of exposure. Generally, the digestive gland is the main organ involved in xenobiotic biotransformation, often generating oxy-radicals as by products (AguirreMartínez et al., 2013b). However, our results demonstrated that the gills were the most responsive organs, showing the highest activity after $48 \mathrm{~h}$ exposure. This may be related to the fact that the gills are the first organs to come into contact with the environmental contaminant and are considered the main interface between the organism, and waterborne pollutants (Trevisan et al., 2016), triggering several reactions aimed at protecting the organism from the toxic effects of xenobiotics present in the aquatic environment (Gonzalez-Rey and Bebianno, 2014). Furthermore, the impact of pharmaceutical exposures on gill physiology are of special interest, since adverse alterations of gills most likely affect oxygen supply and consequently biochemical oxygen-dependent reactions (Hoeger et al., 2005).

The biotransformation of foreign chemicals, including pharmaceuticals, was examined by cytochrome P450 activities responsible for phase 1 biotransformation of lipophilic xenobiotics. Several authors have reported that the induction of EROD and DBF enzymes is directly associated with these biotransformation processes, and this may also occur in mollusks (Gagné et al., 2007; Lopes et al., 2012; Maranho et al., 2015; Siebert et al., 2017). DCF at 200 ng.L ${ }^{-1}$ significantly decreased the activity of the EROD, in accordance with Falfushynska et al. (2014) that observed an inhibition of EROD activity in mussels exposed to NSAIDs. Laville et al. (2004) also reported EROD inhibition in Onchorynchus mykiss exposed to DCF, suggesting that there is a specific interaction between this pharmaceutical or its metabolites and P450 dependent enzymes. Aguirre-Martínez et al. (2016) observed an inhibition of DBF activity in mollusks exposed to anti-inflammatory Ibuprofen (IBU), but in our study the activity of DBF was not affected by DCF. Indeed, there is a gap in knowledge regarding the role of mussels' cytochrome P450 (Aguirre-Martínez et al., 2013b).

GPx and GST activities were also inhibited by DCF. GST represents the major conjugating enzyme in bivalves (Gagné et al., 2007), and contributes to the phase II biotransformation of xenobiotics (Aguirre-Martínez et al., 2013b). Furthermore, in bivalves, GST represents the main conjugating enzyme and plays an important role in phase II biotransformation, especially in digestive gland, while it performs a prevalent antioxidant activity in gills. Our results agree with Schmidt et al. (2014) where a significant reduction in the activity of the antioxidant system of mussels exposed to DCF occurred at concentrations of $1 \mu \mathrm{g} . \mathrm{L}^{-1}$ and $1000 \mu \mathrm{g} . \mathrm{L}^{-1}$, suggesting a potential role of oxidative stress by DCF. Parolini et al. (2009) also showed that DCF caused an inhibition of GST activity in Dreissena polymorpha. Studies conducted by Guiloski et al. (2015) with Hopilas malabaricus exposed to DCF also showed a reduction in GST activity at all concentrations tested $\left(0.2 \mu \mathrm{g} \cdot \mathrm{kg}^{-1}, 2.0 \mu \mathrm{g} . \mathrm{kg}^{-1}\right.$ and $\left.20 \mu \mathrm{g} . \mathrm{kg}^{-1}\right)$, suggesting that biotransformation was inhibited.

GPX is responsible for catalyzing the reduction of hydrogen peroxide and lipid peroxide and a decrease in its activity may indicate that the anti-oxidant capacity was suppressed, favoring the occurrence of lipid peroxidation processes (Lu et al., 2013). Our results indicate a decrease in GPx activity at the concentrations of $200 \mathrm{ng}$. $\mathrm{L}^{-1}$ at T $48 \mathrm{~h}$ and $2000 \mathrm{ng}$. $\mathrm{L}^{-1}$ at T $96 \mathrm{~h}$. This ability of DCF to inhibit GPx activity has also been reported in studies with Cyprinus carpio (Sanjuan-Reyes et al., 2013) and Hopilas malabaricus (Guiloski et al., 2015), and both authors pointed out that inhibition of antioxidant defenses can increase the susceptibility to oxidative stress.

Pharmaceutical compounds are involved in the production of reactive oxygen species (ROS), and are able to cause adverse effects in both target and non-target organisms, besides altering the oxidative state of the cells during the metabolism of xenobiotics (Aguirre-Martínez et al., 2013b). ROS are normally produced by several kinds of chemical compounds such as NSAIDs after the metabolic processes, generating reactive products capable of inducing oxidative stress (Gómez-Oliván et al., 2014), and causing lipid peroxidation, changes in gene expression, DNA damage and inactivation of enzymes can occur especially when the antioxidant defenses are overwhelmed (Diniz et al., 2015). Nevertheless, our results showed a reduction in DNA damage levels in gills exposed to a concentration of $200 \mathrm{ng} . \mathrm{L}^{-1}$ after $48 \mathrm{~h}$ exposure, suggesting that DCF exposure may stimulate another defense or repair mechanism to counteract or prevent DNA damage (Schmidt et al., 2014). Ching et al. (2001) observed that a DNA repair system might be activated after the mussel accumulates sufficient concentrations of toxicants above a specific threshold that enables the repair mechanism.

Genotoxicity was observed only in the digestive gland exposed to $2000 \mathrm{ng}$. $\mathrm{L}^{-1}$ after $48 \mathrm{~h}$ exposure, corroborating with Parolini et al. (2009) who also noted that DCF could induce DNA damage. Ribas et al. (2016) also recorded damage in Hoplias malabaricus 
exposed to a concentration of $0.18 \mathrm{ng} \cdot \mathrm{mL}^{-1}$. DNA damage may generate several negative effects in organism such as mutations, chromosomal changes or carcinogenesis, compromising the reproduction and survival of the organism (Morachis-Valdez et al., 2015).

Malondialdehyde (MDA) content was used as an indicator of lipid peroxidation and our results also showed an MDA increase in gill tissues exposed to concentrations of $200 \mathrm{ng} . \mathrm{L}^{-1}$ after $48 \mathrm{~h}$ exposure. This ability of DCF to induce lipoperoxidation corroborates with Kummerová et al. (2016), which observed damage to cell membranes after an increase of MDA in Lemma minor exposed to DCF. Saucedo-Vence et al. (2015) and Guiloski et al. (2015) also noticed an increase in MDA levels in fishes exposed to this pharmaceutical. Occurrence of LPO in mussels exposed to DCF has been demonstrated in several studies (Quinn et al., 2011; Schmidt et al., 2011; Gonzalez-Rey and Bebianno, 2014). The occurrence of LPO is associated with oxidative stress and may lead to cell injury, protein and membrane damage. Therefore, we believe that this lipoperoxidation process is responsible for the decrease in the lysosomal membrane stability (LMS) observed in the cytotoxicity assay.

DCF possibly contributed to a significant lysosomal damage, specifically lysosomal membrane destabilization in the cytotoxicity assays, since the lysosomes may accumulate several xenobiotics, dyes and drugs (Moore et al., 2008). Therefore, the NRRT assay is based on the fact that healthy cells retain the dye longer compared to lysosomes affected by contaminants, and has been included in environmental quality monitoring studies (Viarengo et al., 2007). When the lysosomal membrane is destabilized, the neutral red will leak into the cytosol of the cell quickly (Lowe and Pipe, 1994), therefore NRR assay is commonly used as a biomarker to monitor marine environments (Francioni et al., 2005; Aguirre-Martínez et al., 2013a).

Our results demonstrated a lysosomal membrane destabilization in all concentrations tested, starting from environmental concentrations of $20 \mathrm{ng} . \mathrm{L}^{-1}$. Parolini et al. $(2009,2012)$ showed a lysosomal membrane destabilization in $D$. polymorpha mussels exposed to concentration of $250 \mu \mathrm{g}$. $\mathrm{L}^{-1}$ of DCF, and $1.5 \mu \mathrm{g} \mathrm{. \textrm {L } ^ { - 1 }}$ of a NSAID mixture. Studies carried out by Aguirre-Martínez et al. (2013a) also observed lysosomal membrane destabilization in mussels exposed to NSAID, with reductions of up to $60 \%$ in the NRRT, corroborating with the data obtained in our study. The lysosomal membrane destabilization is of concern since it may affect the cellular nutrition, immunological defense, besides producing negative effects during embryogenesis, leading to disturbances on larval development (Pereira et al., 2014).

NSAIDs promote the non-selective inhibition of cyclooxygenase isoforms (COX-1 and COX-2), reducing the biosynthesis of proinflammatory prostaglandins (PGs) from phospholipid arachidonic acid (AA) (Fent et al., 2006). Thus, important physiological functions such as water transport, osmoregulation, reproduction and immune defense may be affected (Gonzalez-Rey and Bebianno, 2014). Our results showed an inhibition of COX activity in gill tissues and agree with Gagné et al. (2005), which observed an inhibition of enzymatic activity in Ellipio complanata exposed to the NSAID ibuprofen. Mehinto and Hill (2010) described a significant reduction in the activity of COX-1 and COX-2 in the gills of the fish Oncorhynchus mykiss, leading to a reduction in the production of eicosanoids that may affect blood coagulation, homeostasis and immune response in these organisms. Ardaillou et al. (1987) observed that an increase of ROS is associated to an AA conversion via LOX pathway, while the inverse effect can be found when transformed into prostaglandins via COX pathway, events that are associated with processes of phagocytosis and concentration of hemocytes in invertebrates (Delaporte et al., 2006). Therefore, Gonzalez-Rey and Bebianno (2011) hypothesized that a possible accumulation of AA in cells due to blockage or decrease of COX activity may induce an increase in $\mathrm{H}_{2} \mathrm{O}_{2}$ production, altering the oxidative state of the cells. COX expression has been investigated in bivalve mussels (Gagné et al., 2008). Quinn et al. (2011) observed that mussels exposed to DCF showed higher LPO levels, directly associated with oxidative stress, resulting in the oxidation of polyunsaturated lipids and may be a negative effect of COX-2 inhibition or peroxisome proliferators where oxidation occurs. In aquatic invertebrates, PGs are involved in several important processes as, oogenesis, spermatogenesis, immune defense and ion transport (Rowley et al., 2005; Schmidt et al., 2011).

ChE is one of the most effective biomarkers of xenobiotic-driven neurologic alterations in aquatic species, and its activity is critical for the neuromuscular system. AChE induction is associated with cell apoptosis because AChE is released after cell membrane disruption (Zhang et al., 2002). Measurement of AChE inhibition has been used as a biomarker of effect on nervous system following exposure to emerging pollutants (Lionetto et al., 2013), but our results showed an increased enzymatic activity in gill tissues. These results agree with Gonzalez-Rey and Bebianno (2014) that also observed an induction of AChE activity in Mytilus galloprovincialis exposed to concentration of $250 \mathrm{ng} . \mathrm{L}^{-1}$ DCF. Zhang et al. (2002) noted that AChE induction is associated with cell apoptosis in various mammalian cells, probably because a cell membrane disruption promotes a release of $\mathrm{ChE}$. The cytotoxicity represented by lysosomal membrane disruption, as well as high levels of MDA found in gill tissues, may be related to increased ChE in these tissues. Similarly, Falfushynska et al. (2014) reported an intense apoptotic process in mussels' gills due to high levels of caspase gene expression in these organs, aiming at eliminating damaged cells.

\section{Conclusions}

This study has shown that acute exposure of DCF in order to mg. $\mathrm{L}^{-1}$ was able to impair reproductive parameters of the brown mussel Perna perna. Nevertheless, environmental relevant concentrations triggered cellular and physiological damages through lipid peroxidation, lysosomal membrane destabilization and COX inhibition. These biomarker responses were linked to DCF mode of action. Hazard characterization employing sublethal effects with ecological relevance (e.g. cytotoxicity) provided valuable information on health status disturbances caused by this NSAID to a nontarget marine organism.

\section{Acknowledgments}

This study was funded by CNPq (Processes $n^{\circ} 481358 / 2012-9$ and $\mathrm{n}^{\circ} 481553 / 2012-6$ ). The authors thank FAPESP (Fundação de Amparo à Pesquisa do Estado de São Paulo) for financial support (Grant \#2014/11742-0 and Grant 2006/07005-4). Camilo Dias Seabra Pereira, Augusto Cesar, Denis Abessa and Eduardo Alves Almeida thank CNPq for fellowships.

\section{References}

Aguirre-Martínez, G.V., Buratti, S., Fabbri, E., DelValls, A.T., Martín-Díaz, M.L., 2013a Using lysosomal membrane stability of haemocytes in Ruditapes philippinarum as a biomarker of cellular stress to assess contamination by caffeine, ibuprofen, carbamazepine and novobiocin. J. Environ. Sci. 25, 1408-1418. https://doi.org/ 10.1016/S1001-0742(12)60207-1.

Aguirre-Martínez, G.V., Del Valls, T.A., Martín-Díaz, M.L., 2013b. Identification of biomarkers responsive to chronic exposure to pharmaceuticals in target tissues of Carcinus maenas. Mar. Environ. Res. 87-88, 1-11. https://doi.org/10.1016/ j.marenvres.2013.02.011.

Aguirre-Martínez, G.V., Owuor, M.A., Garrido-Pérez, C., Salamanca, M.J., Del Valls, T.A., Martín-Díaz, M.L., 2015. Are standard tests sensitive enough to evaluate effects of human pharmaceuticals in aquatic biota? Facing changes in research approaches when performing risk assessment of drugs. Chemosphere 
120, 75-85. https://doi.org/10.1016/j.chemosphere.2014.05.087.

Aguirre-Martínez, G.V., DelValls, T.A., Martín-Díaz, M.L., 2016. General stress, detoxification pathways, neurotoxicity and genotoxicity evaluated in Ruditapes philippinarum exposed to human pharmaceuticals. Ecotoxicol. Environ. Saf. 124 18-31. https://doi.org/10.1016/j.ecoenv.2015.09.031.

Ardaillou, R., Baud, L., Sraer, J., 1987. Role of arachidonic acid metabolites and reactive oxygen species in glomerular immune-inflammatory process. Springer Semin. Immunopathol. 9, 371-385. https://doi.org/10.1007/BF00197215.

ASTM, American Society of Testing and Materials, 1992. ASTM E 724-89 Standart guide for conduction static toxicity tests starting with embryos of four species of saltwater mollusks. In: ASTM - American Society for Testing and Materials. Annual Book of ASTM Standards: water and environmental technology, Philadelphia, 11:4:377-394.

Baena-Nogueras, R.M., González-Mazo, E., Lara-Martín, P.A., 2017. Degradation kinetics of pharmaceuticals and personal care products in surface waters: photolysis vs biodegradation. Sci. Total Environ. 590-591, 643-654. https:/ doi.org/10.1016/j.scitotenv.2017.03.015.

Bradford, M., 1976. A rapid and sensitive method for the quantification of microgram quantities of protein utilizing the principle of protein-dye binding. Anal. Biochem. 72, 248-254. https://doi.org/10.1016/0003-2697(76)90527-3.

CETESB. Companhia de Saneamento Básico do Estado de São Paulo, 2016. Qualidade das praias litorâneas no Estado de São Paulo. Available. http://praias.cetesb.sp. gov.br/wp-content/uploads/sites/26/2013/11/relatorio-praias-2016.pdf.

Ching, E.W.K., Siu, W.H.L., Lam, P.K.S., Xu, L., Zhang, Y., Richardson, B.J., Wu, R.S.S 2001. DNA adduct formation and DNA strand breaks in green-lipped mussels (Perna viridis) exposed to benzo[a]pyrene: dose- and time-dependent relationships. Mar. Pollut. Bull. 42, 603-610. https://doi.org/S0025-326X(00) 00209-5.

Cleuvers, M., 2003. Aquatic ecotoxicity of pharmaceuticals including the assessment of combination effects. Toxicol. Lett. 142, 185-194. https://doi.org/10.1016/ S0378-4274(03)00068-7.

Cleuvers, M., 2004. Mixture toxicity of the anti-inflammatory drugs diclofenac, ibuprofen, naproxen, and acetylsalicylic acid. Ecotoxicol. Environ. Saf. 59, 309-315. https://doi.org/10.1016/S0147-6513(03)00141-6.

Delaporte, M., Soudant, P., Moal, J., Giudicelli, E., Lambert, C., 2006. Impact of 20: 4n6 supplementation on the fatty acid composition and hemocyte parameters of the Pacific Oyster Crassostrea gigas. Lipids 41, 567-576. https://doi.org/10.1007/ s11745-006-5006-9.

Diniz, M.S., Salgado, R., Pereira, V.J., Carvalho, G., Oehmen, A., Reis, M.A., Noronha, J.P., 2015. Ecotoxicity of ketoprofen, diclofenac, atenolol and their photolysis byproducts in zebrafish (Danio rerio). Sci. Total Environ. 505, 282-289. https://doi.org/10.1016/j.scitotenv.2014.09.103.

Eades, C., Waring, C.P., 2010. The effects of diclofenac on the physiology of the green shore crab Carcinus maenas. Mar. Environ. Res. 69, S46-S48. https://doi.org 10.1016/j.marenvres.2009.11.001.

Ellman, G.L., Courtney, K.D., Andres Jr., V., Featherstone, R.M., 1961. A new and rapid colorimetric determination of acetylcholinesterase activity. Biochem. Pharmacol. 7, 88-95. https://doi.org/10.1016/0006-2952(61)90145-9.

Ericson, H., Thorsén, G., Kumblad, L., 2010. Physiological effects of diclofenac, ibuprofen and propranolol on Baltic Sea blue mussels. Aquat. Toxicol. 99, 223-231. https://doi.org/10.1016/j.aquatox.2010.04.017.

European Commission, 2013. Directive 2013/39/EU of 12 August 2013 Amending Directives 2000/60/EC and 2008/105/EC as Regards Priority Substances in the Field of Water Policy. Directive.

Fabbri, R., Montagna, M., Balbi, T., Raffo, E., Palumbo, F., Canesi, L., 2014. Adaptation of the bivalve embryotoxicity assay for the high throughput screening of emerging contaminants in Mytilus galloprovincialis. Mar. Environ. Res. 99, 1-8. https://doi.org/10.1016/j.marenvres.2014.05.007.

Falfushynska, H.I., Gnatyshyna, L.L., Osadchuk, O.Y., Farkas, A., Vehovszky, A. Carpenter, D.O., Gyori, J., Stoliar, O.B., 2014. Diversity of the molecular response to separate wastewater effluents in freshwater mussels. Comp. Biochem. Physiol. C Toxicol. Pharmacol. 164, 51-58. https://doi.org/10.1016/ j.cbpc.2014.04.007.

Fang, T.H., Nan, F.H., Chin, T.S., Feng, H.M., 2012. The occurrence and distribution of pharmaceutical compounds in the effluents of a major sewage treatment plant in Northern Taiwan and the receiving coastal waters. Mar. Pollut. Bull. 64 (7) 1435-1444. https://doi.org/10.1016/j.marpolbul.2012.04.008.

Feito, R., Valcárcel, Y., Catalá, M., 2012. Biomarker assessment of toxicity with miniaturised bioassays: diclofenac as a case study. Ecotoxicology 21, 289-296. https://doi.org/10.1007/s10646-011-0790-2.

Fent, K., Weston, A.A., Caminada, D., 2006. Ecotoxicology of human pharmaceuticals. Aquat Toxicol. 76, 122-159. https://doi.org/10.1016/j.aquatox.2005.09.009.

Ferrari, B., Paxéus, N., Lo Giudice, R., Pollio, A., Garric, J., 2003. Ecotoxicological impact of pharmaceuticals found in treated wastewaters: study of carbamaz epine, clofibric acid, and diclofenac. Ecotoxicol. Environ. Saf. 55, 359-370. https://doi.org/10.1016/S0147-6513(02)00082-9.

Francioni, E., Wagener, A., Scofield, A.L., Cavalier, B., 2005. Biomonitoring of polycyclic aromatic hydrocarbon in Perna perna from Guanabara Bay. Brazil. Environ. Forensics 6, 361-370. https://doi.org/10.1080/15275920500351759.

Fujimoto, Y., Sakuma, S., Inoue, T., Uno, E., Fujita, T., 2002. The endocrine disruptor nonylphenol preferentially blocks cyclooxygenase-1. Life Sci. 70, 2209-2214. https://doi.org/10.1016/S0024-3205(01)01538-7.

Gagné, F., Blaise, C., 1993. Hepatic metallothionein level and mixed function oxidase activity in fingerling rainbow trout (Oncorhynchus mykiss) after acute exposure to pulp and paper mill effluents. Water Res. 27, 1669-1682. https://doi.org/
10.1016/0043-1354(93)90131-Z.

Gagné, F., Trottier, S., Blaise, C., Sproull, J., Ernst, B., 1995. Genotoxicity of sediment extracts obtained in the vicinity of a creosote-treated wharf to rainbow trout hepatocytes. Toxicol. Lett. 78, 175-182. https://doi.org/10.1016/0378-4274(95) 03259-N.

Gagné, F., Bérubé, E., Fournier, M., Blaise, C., 2005. Inflammatory properties of municipal effluents to Elliptio complanata mussels-lack of effects from antiinflammatory drugs. Comp. Biochem. Physiol. C Toxicol. Pharmacol. 141, 332-337. https://doi.org/10.1016/j.cca.2005.06.006.

Gagné, F., André, C., Cejka, P., Gagnon, C., Blaise, C., 2007. Toxicological effects of primary-treated urban wastewaters, before and after ozone treatment on freshwater mussels (Elliptio complanata). Comp. Biochem. Physiol. C Toxicol. Pharmacol. 145, 542-552. https://doi.org/10.1016/j.cbpc.2007.01.019.

Gagné, F., Andre, C., Cejka, P., Hausler, R., Fournier, M., Blaise, C., 2008. Immunotoxic effects on freshwater mussels of a primary-treated wastewater before and after ozonation: a pilot plant study. Ecotoxicol. Environ. Saf. 69, 366-373. https:// doi.org/10.1016/j.ecoenv.2007.10.027.

Gómez-Oliván, L.M., Galar-Martínez, M., García-Medina, S., Valdés-Alanís, A., IslasFlores, H., Neri-Cruz, N., 2014. Genotoxic response and oxidative stress induced by diclofenac, ibuprofen and naproxen in Daphnia magna. Drug Chem. Toxicol. 37, 391-399. https://doi.org/10.3109/01480545.2013.870191.

Gonzalez-Rey, M., Bebianno, M.J., 2011. Non-steroidal anti-inflammatory drug (NSAID) ibuprofen distresses antioxidant defense system in mussel Mytilus galloprovincialis gills. Aquat. Toxicol. 105, 264-269. https://doi.org/10.1016/ j.aquatox.2011.06.015.

Gonzalez-Rey, M., Bebianno, M.J., 2014. Effects of non-steroidal anti-inflammatory drug (NSAID) diclofenac exposure in mussel Mytilus galloprovincialis. Aquat. Toxicol. 148, 221-230. https://doi.org/10.1016/j.aquatox.2014.01.011.

Gröner, F., Ziková, A., Kloas, W., 2015. Effects of the pharmaceuticals diclofenac and metoprolol on gene expression levels of enzymes of biotransformation, excretion pathways and estrogenicity in primary hepatocytes of Nile tilapia (Oreochromis niloticus). Comp. Biochem. Physiol. C Toxicol. Pharmacol. 167, 51-57. https://doi.org/10.1016/j.cbpc.2014.09.003.

Gröner, F., Höhne, C., Kleiner, W., Kloas, W., 2017. Chronic diclofenac exposure affects gill integrity and pituitary gene expression and displays estrogenic activity in nile tilapia (Oreochromis niloticus). Chemosphere 166, 473-481. https:// doi.org/10.1016/j.chemosphere.2016.09.116.

Gros, M., Rodríguez-Mozaz, S., Barceló, D., 2012. Fast and comprehensive multiresidue analysis of a broad range of human and veterinary pharmaceuticals and some of their metabolites in surface and treated waters by ultra-highperformance liquid chromatography coupled to quadrupole-linear ion trap tandem mass spectrometry. J. Chromatogr. A 1248, 104-121. https://doi.org/ 10.1016/j.chroma.2012.05.084.

Guiloski, I.C., Luiz, J., Ribas, C., Pereira, S., Paula, A., Neves, P., Cristina, H., Assis, S., 2015. Ecotoxicology and Environmental Safety Effects of trophic exposure to dexamethasone and diclofenac in freshwater fish. Ecotoxicol. Environ. Saf. 114, 204-211. https://doi.org/10.1016/j.ecoenv.2014.11.020.

Han, G., Hur, H., Kim, S., 2006. Ecotoxicological risk of pharmaceuticals from wastewater treatment plants in Korea, occurence and toxicity to Daphnia magna. Environ. Toxicol. Chem. 25, 265-271. https://doi.org/10.1897/05-193R.1.

Heberer, T., Feldmann, D., 2005. Contribution of effluents from hospitals and private households to the total loads of diclofenac and carbamazepine in municipal sewage effluents-modeling versus measurements. J. Hazard Mater. 122, 211-218. https://doi.org/10.1016/j.jhazmat.2005.03.007.

Hernando, M.D., Mezcua, M., Fernández-Alba, a R., Barceló, D., 2006. Environmental risk assessment of pharmaceutical residues in wastewater effluents, surface waters and sediments. Talanta 69, 334-342. https://doi.org/10.1016/ j.talanta.2005.09.037.

Hoeger, B., Köllner, B., Dietrich, D.R., Hitzfeld, B., 2005. Water-borne diclofenac affects kidney and gill integrity and selected immune parameters in brown trout (Salmo trutta f. fario). Aquat. Toxicol. 75, 53-64. https://doi.org/10.1016/ j.aquatox.2005.07.006.

Hong, Y.L., Yeh, S.L., Chang, C.Y., Hu, M.L., 2000. Total plasma malondialdehyde levels in 16 Taiwanese college students determined by various thiobarbituric acid tests and an improved high-performance liquid chromatography-based method. Clin. Biochem. 33, 619-625. https://doi.org/10.1016/S0009-9120(00) 00177-6.

NWRI Scientific Assessment Report Series No.8. In: Kleywegt, S., Smyth, S.A., Parrott, J., Schaefer, K., Lagacé, E., Payne, M., Topp, E., Beck, A., McLaughlin, A. Ostapyk, K. (Eds.), 2007. Pharmaceuticals and Personal Care Products in the Canadian Environment: Research and Policy Directions, p. 53.

Kummerová, M., Zezulka, Š., Babula, P., Tříska, J., 2016. Possible ecological risk of two pharmaceuticals diclofenac and paracetamol demonstrated on a model plant Lemna minor. J. Hazard Mater. 302, 351-361. https://doi.org/10.1016/ j.jhazmat.2015.09.057.

Laville, N., Aït-Aïssa, S., Gomez, E., Casellas, C., Porcher, J.M., 2004. Effects of human pharmaceuticals on cytotoxicity, EROD activity and ROS production in fish hepatocytes. Toxicology 196, 41-55. https://doi.org/10.1016/j.tox.2003.11.002.

Lionetto, M.G., Caricato, R., Calisi, A., Giordano, M.E., Schettino, T., 2013. Acetylcholinesterase as a biomarker in environmental and occupational medicine: new insights and future perspectives. Bio Med Res. Intern 2013 (8). https:// doi.org/10.1155/2013/3.

Liu, Y., Wang, L., Pan, B., Whang, C., Bao, S., Nie, X., 2017. Toxic effects of diclofenac on life history parameters and the expression of detoxification-related genes in Daphnia magna. Aquatic Toxic. 183, 104-113. https://doi.org/10.1016/ 
j.aquatox.2016.12.020, 0166-445.

Lolić, A., Paíga, P., Santos, L.H.M.L.M., Ramos, S., Correia, M., Delerue-Matos, C., 2015 Assessment of non-steroidal anti-inflammatory and analgesic pharmaceuticals in seawaters of North of Portugal: occurrence and environmental risk. Sci. Total Environ. 508, 240-250. https://doi.org/10.1016/j.scitotenv.2014.11.097.

Lopes, B., Ferreira, a M., Bebianno, M.J., 2012. Responses of CYP450 dependent system to aliphatic and aromatic hydrocarbons body burden in transplanted mussels from South coast of Portugal. Ecotoxicology 21, 730-749. https:// doi.org/10.1007/s10646-011-0834-7.

Lowe, D.M., Pipe, R.K., 1994. Contaminant induced lysosomal membrane damage in marine mussel digestive cells: an in vitro study. Aquat. Toxicol. 30, 357-365. https://doi.org/10.1016/0166-445X(94)00045-X.

Lu, G., Yang, X., Li, Z., Zhao, H., Wang, C., 2013. Contamination by metals and pharmaceuticals in northern Taihu Lake (China) and its relation to integrated biomarker response in fish. Ecotoxicology 22, 50-59. https://doi.org/10.1007/ s10646-012-1002-4.

Maranho, L.A., DelValls, T.A., Martín-Diaz, M.L., 2015. Assessing potential risks of wastewater discharges to benthic biota: an integrated approach to biomarker responses in clams (Ruditapes philippinarum) exposed under controlled conditions. Mar. Pollut. Bull. 92, 11-24. https://doi.org/10.1016/ j.marpolbul.2015.01.009.

McClellan, K., Halden, R.U., 2010. Pharmaceuticals and personal care products in archived U.S. biosolids from the 2001 EPA National Sewage Sludge Survey. Water Res. 44, 658-668. https://doi.org/10.1016/j.watres.2009.12.032.

McFarland, V.A., Inouye, L.S., Lutz, C.H., Jarvis, A.S., Clarke, J.U., Mccant, D.D., 1999. Biomarkers of oxidative stress and genotoxicity in livers of field-collected brown bullhead, Ameiurus nebulosus. Arch. Environ. Contam. Toxicol. 241, 236-241. https://doi.org/10.1007/s002449900510.

Mehinto, A.C., Hill, E.M., 2010. Uptake and biological effects of environmentally relevant concentrations of the nonsteroidal anti-inflammatory pharmaceutical diclofenac in rainbow trout (Oncorhynchus mykiss ). Environ. Sci. Technol. 44, 2176-2182. https://doi.org/10.1021/es903702m.

Moore, M.N., Kohler, A., Lowe, D., Viarengo, A., 2008. Lysosomes and autophagy in aquatic animals. Meth. Enzymol. 451, 581-620. https://doi.org/10.1016/S00766879(08)03233-3.

Morachis-Valdez, G., Dublán-García, O., López-Martínez, L.X., Galar-Martínez, M., Saucedo-Vence, K., Gómez-Oliván, L.M., 2015. Chronic exposure to pollutants in Madín Reservoir (Mexico) alters oxidative stress status and flesh quality in the common carp Cyprinus carpio. Environ. Sci. Pollut. Res. 22, 9159-9172. https:// doi.org/10.1007/s11356-014-4061-7.

Munari, M., Chemello, C., Finos, L., Ingrosso, G., Giani, M., Marin, M.G., 2016. Coping with seawater acidification and the emerging contaminant diclofenac at the larval stage: a tale from the clam Ruditapes philippinarum. Chemosphere 160, 293-302. https://doi.org/10.1016/j.chemosphere.2016.06.095, 0045-6535.

Olive, P.L., 1988. DNA precipitation assay: a rapid and simple method for detecting DNA damage in mammalian cells. Environ. Mol. Mutagen. 11, 487-495. https:// doi.org/10.1002/em.2850110409.

Parolini, M., Binelli, A., Cogni, D., Riva, C., Provini, A., 2009. An in vitro biomarker approach for the evaluation of the ecotoxicity of non-steroidal anti-inflammatory drugs (NSAIDs). Toxicol. In Vitro 23, 935-942. https://doi.org/10.1016/ j.tiv.2009.04.014.

Parolini, M., Binelli, A., Quinn, B., Provini, A., 2011. Cytotoxicity assessment of four pharmaceutical compounds on the zebra mussel (Dreissena polymorpha) haemocytes, gill and digestive gland primary cell cultures. Chemosphere 84 91-100. https://doi.org/10.1016/j.chemosphere.2011.02.049.

Parolini, M., Binelli, A., 2012. Sub-lethal effects induced by a mixture of three nonsteroidal anti-inflammatory drugs (NSAIDs) on the freshwater bivalve Dreissena polymorpha. Ecotoxicology 21, 379-392. https://doi.org/10.1007/s106460110799-6.

Pereira, C.D.S., Abessa, D.M.S., Choueri, R.B., Almagro-Pastor, V., Cesar, A., Maranho, L.A., Martín-Díaz, M.L., Torres, R.J., Gusso-Choueri, P.K., Almeida, J.E., Cortez, F.S., Mozeto, A.A., Silbiger, H.L.N., Sousa, E.C.P.M., Del Valls, T.A. Bainy, A.C.D., 2014. Ecological relevance of Sentinels' biomarker responses: a multi-level approach. Mar. Environ. Res. 96, 118-126. https://doi.org/10.1016/ j.marenvres.2013.11.002.

Pereira, C.D.S., Maranho, L.A., Cortez, F.S., Pusceddu, F.H., Santos, A.R., Ribeiro, D.A., Cesar, A., Guimarães, L.L., 2016. Occurrence of pharmaceuticals and cocaine in a Brazilian coastal zone. Sci. Total Environ. 548-549, 148-154. https://doi.org/ 10.1016/j.scitotenv.2016.01.051.

Poirier-Larabie, S., Segura, P.A., Gagnon, C., 2016. Degradation of the pharmaceuticals diclofenac and sulfamethoxazole and their transformation products under controlled environmental conditions. Sci. Total Environ. 557-558, 257-267. https://doi.org/10.1016/j.scitotenv.2016.03.057.

Quinn, B., Schmidt, W., O'Rourke, K., Hernan, R., 2011. Effects of the pharmaceuticals gemfibrozil and diclofenac on biomarker expression in the zebra musse (Dreissena polymorpha) and their comparison with standardised toxicity tests. Chemosphere 84, 657-663. https://doi.org/10.1016/j.chemosphere.2011.03.033.

Ribas, J.L.C., Zampronio, A.R., Silva de Assis, H.C., 2016. Effects of trophic exposure to diclofenac and dexamethasone on hematological parameters and immune response in freshwater fish. Environ. Toxicol. Chem. 35, 975-982. https:// doi.org/10.1002/etc.3240.

Rittschof, D., McClellan-Green, P., 2005. Molluscs as multidisciplinary models in environment toxicology. Mar. Pollut. Bull. 50, 369-373. https://doi.org/10.1016/ j.marpolbul.2005.02.008.

Rodil, R., Quintana, J.B., Concha-Graña, E., López-Mahía, P., Muniategui-Lorenzo, S. Prada-Rodríguez, D., 2012. Emerging pollutants in sewage, surface and drinking water in Galicia (NW Spain). Chemosphere 86, 1040-1049. https://doi.org/ 10.1016/j.chemosphere.2011.11.053.

Rowley, A.F., Vogan, C.L., Taylor, G.W., Clare, A.S., 2005. Prostaglandins in noninsectan invertebrates: recent insights and unsolved problems. J. Exp. Biol. 208, 3-14. https://doi.org/10.1242/jeb.01275.

Sanjuan-Reyes, N., Gómez-Oliván, L.M., Galar-Martínez, M., Vieyra-Reyes, P., GarcíaMedina, S., Islas-Flores, H., Neri-Cruz, N., 2013. Effluent from an NSAIDmanufacturing plant in Mexico induces oxidative stress on Cyprinus Carpio. Water Air Soil Pollut. 224 (1689) https://doi.org/10.1007/s11270-013-1689-8.

Saucedo-Vence, K., Dublán-García, O., López-Martínez, L.X., Morachis-Valdes, G. Galar-Martínez, M., Islas-Flores, H., Gómez-Oliván, L.M., 2015. Short and longterm exposure to diclofenac alter oxidative stress status in common carp Cyprinus carpio. Ecotoxicology 24, 527-539. https://doi.org/10.1007/s10646014-1401-9.

Schmidt, W., O'Rourke, K., Hernan, R., Quinn, B., 2011. Effects of the pharmaceuticals gemfibrozil and diclofenac on the marine mussel (Mytilus spp.) and their comparison with standardized toxicity tests. Mar. Pollut. Bull. 62, 1389-1395. https://doi.org/10.1016/j.marpolbul.2011.04.043.

Schmidt, W., Rainville, L.-C., McEneff, G., Sheehan, D., Quinn, B., 2014. A proteomic evaluation of the effects of the pharmaceuticals diclofenac and gemfibrozil on marine mussels (Mytilus spp.): evidence for chronic sublethal effects on stressresponse proteins. Drug Test. Anal. 6, 210-219. https://doi.org/10.1002/ dta.1463.

Siebert, M.N., Mattos, J.J., Piazza, C.E., De Lima, D., Gomes, C.H.A.M., De Melo, C.M.R., Bainy, A.C.D., 2017. Characterization of Ethoxyresorufin O-Deethylase activity (EROD) in oyster Crassostrea brasiliana. Comp. Biochem. Physiol. B Biochem. Mol. Biol. 203, 115-121. https://doi.org/10.1016/j.cbpb.2016.10.002.

Trevisan, R., Mello, D.F., Delapedra, G., Silva, D.G.H., Arl, M., Danielli, N.M., Metian, M., Almeida, E. a, Dafre, A.L., 2016. Gills as a glutathione-dependent metabolic barrier in Pacific oysters Crassostrea gigas: absorption, metabolism and excretion of a model electrophile. Aquat. Toxicol. 173, 105-119. https:// doi.org/10.1016/j.aquatox.2016.01.008.

Triebskorn, R., Casper, H., Heyd, A., Eikemper, R., Köhler, H.-R., Schwaiger, J., 2004 Toxic effects of the non-steroidal anti-inflammatory drug diclofenac. Part II: cytological effects in liver, kidney, gills and intestine of rainbow trout (Oncorhynchus mykiss). Aquat. Toxicol. 68, 151-166. https://doi.org/10.1016/ j.aquatox.2004.03.015.

USEPA United States Environmental Protection Agency, 2002. EPA/600/4-91/003 Short-term Methods for Estimating the Chronic Toxicity of Effluents and Receiving Waters to Marine and Estuarine Organisms. U.S. Environmental Protection Agency, Cincinati, p. 579.

van den Brandhof, E.-J., Montforts, M., 2010. Fish embryo toxicity of carbamazepine, diclofenac and metoprolol. Ecotoxicol. Environ. Saf. 73, 1862-1866. https:// doi.org/10.1016/j.ecoenv.2010.08.031.

Viarengo, A., Lowe, D., Bolognesi, C., Fabbri, E., Koehler, A., 2007. The use of biomarkers in biomonitoring: a 2-tier approach assessing the level of pollutantinduced stress syndrome in sentinel organisms. Comp. Biochem. Physiol. C Toxicol. Pharmacol. 146, 281-300. https://doi.org/10.1016/j.cbpc.2007.04.011.

Wille, K., Noppe, H., Verheyden, K., Vanden Bussche, J., De Wulf, E., Van Caeter, P. Janssen, C.R., De Brabander, H.F., Vanhaecke, L., 2010. Validation and application of an LC-MS/MS method for the simultaneous quantification of 13 pharmaceuticals in seawater. Anal. Bioanal. Chem. 397, 1797-1808. https://doi.org/ 10.1007/s00216-010-3702-z.

Zaroni, L.P., Abessa, D.M.S., Lotufo, G.R., Sousa, E.C.P.M., Pinto, Y.A., 2005. Toxicity testing with embryos of marine mussels: protocol standardization for Perna perna (linnaeus, 1758). Bull. Environ. Contam. Toxicol. 74, 793-800. https:/ doi.org/10.1007/s00128-005-0651-X.

Zhang, X.J., Yang, L., Zhao, Q., Caen, J.P., He, H.Y., Guo, L.H., Alemany, M., Zhang, L.Y., Shi, Y.F., 2002. Induction of acetylcholinesterase expression during apoptosis in various cell types. Cell Death Differ. 9, 790-800. https://doi.org/10.1038/ sj.cdd. 4401034 